Cinémas

Revue d'études cinématographiques

Journal of Film Studies

\title{
Gender Trouble in Hongkong Cinema
}

\section{Tammy Cheung et Michael Gilson}

Volume 3, numéro 2-3, printemps 1993

Le nouveau cinéma chinois

URI : https://id.erudit.org/iderudit/1001198ar

DOI : https://doi.org/10.7202/1001198ar

Aller au sommaire du numéro

\section{Éditeur(s)}

Cinémas

ISSN

1181-6945 (imprimé)

1705-6500 (numérique)

Découvrir la revue

Citer cet article

Cheung, T. \& Gilson, M. (1993). Gender Trouble in Hongkong Cinema. Cinémas, 3(2-3), 181-201. https://doi.org/10.7202/1001198ar

\section{Résumé de l'article}

Cet article fait le point sur le cinéma contemporain de Hongkong en se penchant plus particulièrement sur des questions entourant les représentations de personnages féminins et masculins. Les films, la société et la culture du Hongkong d'aujourd'hui commencent à peine à s'intéresser à la réalité gaie et lesbienne, et, dans une certaine mesure, au féminisme. Comment les différents types de personnages féminins sont-ils présentés dans le cinéma contemporain de Hongkong? Comment le concept traditionnel chinois de " mâle " diffère-t-il de celui que nous connaissons en Occident? La popularité récente de personnages transsexuels dans plusieurs films est aussi examinée. Les auteurs soutiennent que des représentations stéréotypées de personnages féminins, masculins et homosexuels prédominent dans l'industrie cinématographique de Hongkong et que les représentations positives de gais et de lesbiennes y sont le plus souvent absentes. 


\title{
Gender Trouble in Hongkong Cinema
}

\section{Tammy Cheung and Michael Gilson}

\begin{abstract}
RÉSUMÉ
Cet article fait le point sur le cinéma contemporain de Hongkong en se penchant plus particulièrement sur des questions entourant les représentations de personnages féminins et masculins. Les films, la société et la culture du Hongkong d'aujourd'hui commencent à peine à s'intéresser à la réalité gaie et lesbienne, et, dans une certaine mesure, au féminisme. Comment les différents types de personnages féminins sont-ils présentés dans le cinéma contemporain de Hongkong? Comment le concept traditionnel chinois de "mâle» diffère-t-il de celui que nous connaissons en Occident? La popularité récente de personnages transsexuels dans plusieurs films est aussi examinée. Les auteurs soutiennent que des représentations stéréotypées de personnages féminins, masculins et homosexuels prédominent dans l'industrie cinématographique de Hongkong et que les représentations positives de gais et de lesbiennes y sont le plus souvent absentes.
\end{abstract}

\begin{abstract}
The authors conduct a brief survey of some recent examples of the Hongkong cinema, focusing on questions surrounding the portrayals of female and male characters in them. Today's Hongkong films, society and culture are just now taking tentative steps towards an awareness of gay and lesbian themes, and in some measure, of feminism. How are different types of female characters presented in contemporary Hongkong cinema? How does the traditional Chinese view of "male" differ from the West's? The recent trend that has "gender-bending" characters appearing in a number of Hongkong feature films is also examined. The authors maintain that stereotypical representations of women,
\end{abstract}


men, and homosexual characters persist in the Hongkong film industry, that honest portrayals of gay and lesbian characters are mostly absent from the movie screens of the Crown Colony.

\section{Who Are the Women in Hongkong Cinema?}

\section{Tammy Cheung}

Hongkong, the tiny but densely populated colony of the United Kingdom, has been enjoying enviable economic growth despite its uncertain future - by 1997, communist China will take the territory's sovereignty back from the British government.

Besides being one of the richest communities in Asia, Hongkong is also the most Westernized society in the East. Under British rule, Hongkong has modeled almost all of its social systems, from education to its legal structure, after its English colonisers.

From the 1960 s until the early 1980 s, a period of flowering of Hongkong's economy, many students at elite high schools chose to study French instead of Chinese as a "second language," preferred European history to Chinese history. Young people have been embracing Western pop culture - from music to movies to fashion - whole-heartedly. However, Hongkong society is neither very British nor American. If Hongkong were likened to a building, its facade would be Western, but its foundation, virtually, is Confucian. This traditional Chinese value system, despite being declared as reactionary by the communist rulers on the mainland, still dominates the consciousness of the inhabitants of the Crown Colony.

The essence of Confucianism is harmony and stability, as opposed to the Western spirit of competition and progress. According to this traditional theory, a society is comprised of three basic units - individual, family, and community. Each member of these units is placed, according to gender and age, in a patriarchal hierarchy. Women are inferior to men. Wife is to submit to husband. A daughter's status is lesser than a son's. Everyone is to stay in their assigned social role faithfully, thus to ensure the stable continuation of the societal pattern, generation after generation. Any attempt to cross the boundary of one's role 
is destructive to the tightly guarded hierarchy; thus individual ambition is to be completely discouraged.

Since the $80 \mathrm{~s}$, the majority of the population in the colony has started to enjoy the result of their hard work and to emerge from the working class to the middle class. The women of my mother's generation went to work mostly out of economic necessity. Today, a woman who is married, unlike her counterparts in Japan, often still keeps her job. There are more and more women, especially those from middle-class families, who join the work force not simply for economic reasons, but for the identity and meaning attached to jobs. Nowadays, practical-minded employers recognize that women are not necessarily indecisive, narrowminded or lacking in vision, and usually are cheaper to hire. Hence, many women today have moved to positions and fields that were unthinkable to their mothers before them.

Women's liberation, the most important social movement of the last few decades, did not reach the colony the way McDonald's and Levi's jeans did. However, the new economic power has freed Hongkong women from dependency and traditional responsibilities to a great degree. And yet, to the people in Hongkong, "feminism" perhaps sounds too foreign, too militant. During a press conference recently, ${ }^{1}$ Sylvia Chang, a veteran Hongkong actress-director-producer, was asked whether her romantic comedy Sisters of the World Unite, ${ }^{2}$ about two sisters' love adventures, was a "feminist" film. She gave a firm No. And she went on to clarify that she herself was not a "feminist." The rather strong reaction to the "feminist" question from this otherwise soft-spoken, mild-mannered star made me wonder how the concept "feminism" - or the role of "woman," for that matter - is actually presented on the silver screen in Hongkong. Considering Ms Chang is one of the very few female filmmakers to take a genuine interest in stories about women, ${ }^{3}$ her rather negative attitude towards feminism (in its broad sense) is quite telling.

The modern economy gives women access to jobs traditionally held by men, thus the traditional definition of women is subverted. Not long ago, a wife used to be politely referred to by her husband as an "inner person" (neiren), while the man was the "outer person" (wairen). Their titles clearly define where they belong : domestic vs. social and political, subordinate vs. superior. A woman's principal role is to be a quiet and loyal supporter to her men - her father, husband and son(s). A woman who does more than she is assigned to invites scandal, or even discipline. 
After surveying more than one hundred Hongkong films made between 1989 and early 1993, I have realized that women have an even more regressive role on the screen than in reality. Female characters often serve only as wallpaper, victims awaiting rescue, or objects to be pursued, and actually there are not many women in leading roles. Amongst the 125 films released in 1991, for example, about $10 \%$ have all-male casts $4 ; 70 \%$ have male stars as leads and female stars in supporting roles 5 ; and only $5 \%$ have actresses in leading roles 6 . Besides the fact that the "quantity" of the female presence on the screen is disproportionately low, the "quality" is not particularly encouraging either. In the gangster genre, for example, ${ }^{7}$ women are mainly calculating mistresses, self-sacrificing wives or love interests (To Be Number One, Lee Rock I \& II, God of Gamblers III $)$. In comedies, the everpopular genre, women and their bodies are the standard targets of jokes (Magnificent Scoundrels, Armour of God II, Once a Thief ${ }^{9}$ ).

With more Hongkong women crossing the traditional role boundary, giving orders to men, paying household bills, giving up marriage for career, are women still woman enough in a traditional sense? "Iron Lady," 10 a term which started to become popular in the late 70 s to describe a woman who is either a highlevel executive or a successful entrepreneur, is often more a criticism than a compliment. The Iron Lady is seen as a woman who trades in her own nature, femininity, for power and success. She is usually ruthless and manipulative rather than sensitive and giving. In Hongkong's material-crazy society where success is the ultimate goal in life, a woman's success always invites unwanted sympathy and suspicion. She is probably not often asked out by gentlemen callers, if she is single; if she is married, it can only be to a wimp - not a real man.

The Iron Ladies in Hongkong movies are not well-liked by their creators either. In Swordsman Hunt, 11 a martial-arts film about the eternal quest for both power and love, Michelle Yeoh plays a powerful but lonely woman warrior who loses her true love to an innocent, bubbly cutie (played by Wong Tsu-hsien) who has no ambition other than to please her man. In the end, Yeoh has the world at her feet, but she is no happier. Unlike the other woman, she does not have a man and a family. Her power is her weakness; her ambition has destroyed a vital part of her being - her femininity. Yeoh's character brings to mind the lunatic unloved career woman Glenn Close played in Fatal Attraction, who has become perhaps the most hated female character in film history and a perfect example of the "backlash" against the women's movement. 
In the costume martial-arts extravaganza Swordsman II, 12 Lin Ching-hsia plays a Ming Dynasty high priest who has been searching for a sacred scroll that grants its owner supreme power in the martial and supernatural arts. The "price" of this power, however, is the emasculation of its user and his gradual transformation into a woman. As a woman, even though she is the mightiest human being in the world, "Invincible Asia" cannot escape the fate that an Iron Lady is doomed to. Like the lonely warrior of Swordsman Hunt, Invincible Asia also hungers for romantic love. In spite of her unconditional love and loyalty to Swordsman Ling, her devotion goes unrewarded.

It is perhaps more important to point out that Invincible Asia's situation is more complex than that of her counterpart in Swordsman Hunt. The question is : Is she a bona fide woman or still a man? It would seem the filmmakers prefer to leave the question open. Perhaps a powerful woman is not a real woman anymore.

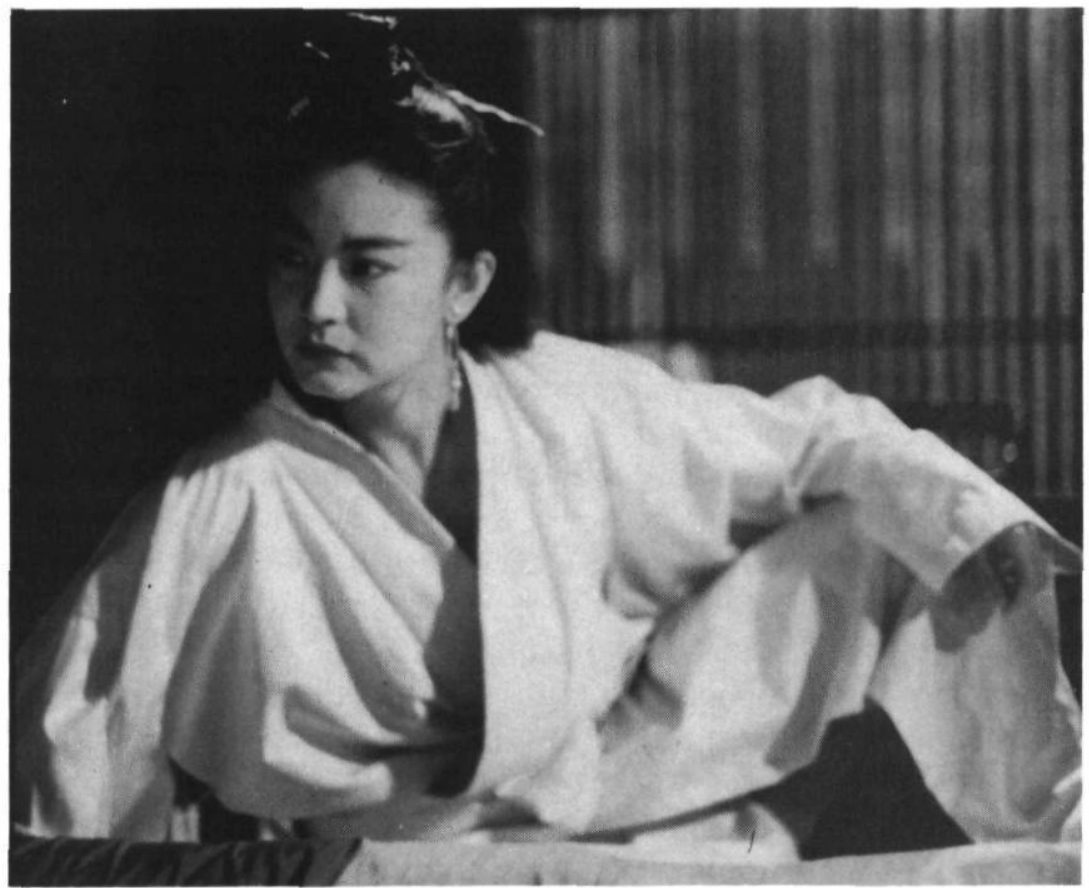

Swordsman II de Ching Siu-Tung (1992) 
I found the most striking scene in Swordsman II to be the moment when Invincible Asia's enemy learns her new sexual identity; he bursts into laughter. Instead of fearing her newlygained fearsome power, he simply dismisses her as a genuine threat. Despite the fact that she can destroy anything at will, including the gentleman who laughs at her, she is still a loser she has lost the superior (male) identity. For my part, I always enjoy being a female, even though I do not know the experience of being a male. It did not occur to me that not being a man is something one can feel deeply regretful about, and being the "other sex" could be a laughable condition. After seeing Swordsman II, I could not help but feel insulted.

Invincible Asia not only loses her man, but loses her own life as well. The cause of her eventual fall, it seems, lies with the negative side of her femininity - being emotional rather than rational. Asia is too sentimental not to sacrifice herself to save her lover's life. A woman with power is contradictory by definition, thus her tragedy is inevitable.

In Hongkong cinema, women may be able to fly like Superman, kill the evildoers and protect the innocent, but the good women warriors always remember who their actual bosses are and what their real callings are. Anita Mui, the bad girl of Hongkong pop music, plays the loyal, childish but "fist-strong" wife of Stephen Chiau in the period martial-arts comedy Justice, My Foot! ${ }^{13}$ Mui and Chiau are a "perfect" couple : Mui protects her magistrate husband with her deadly kung fu while Chiau guides and enlightens his illiterate wife with his scholarly knowledge and wisdom. An Iron Lady without much brains is much more likeable : her feminine role as subordinate to men is intact despite her physical strength. A similar character - the scatterbrained, loving wife of an intellectual - is incarnated by Siu Fong-fong in Fong Sai-yuk. ${ }^{14}$ Like Mui, Siu is better at using her fists than her head. Though she is the mother of an adult son, Siu behaves like a teenager and constantly gets herself into trouble. After she is beaten by her husband in front of a group of relatives as punishment for one of her silly misdemeanors, her son asks why she did not resist; Siu answers that a man's status is very important. She could not let her husband lose face. Notwithstanding the fact that the story supposedly takes place more than a century ago, the film has a modern aura whereby its characters behave like contemporary Hongkong people. In essence, Fong Sai-yuk is a modern comedy dressed in Qing Dynasty costume. Thus, I find the film's endorsement of wife-beating to be appalling, even criminal. By setting their characters in a society where the 
"gentleman scholar" was the most respectable class, are the filmmakers telling us that it is acceptable for a wife to be beaten into a swollen mess as long as her punisher is an intellectual?

It is quite ironic to see Anita Mui and Siu Fong-fong, two of the most influential women in the Hongkong film industry, ${ }^{15}$ playing such silly, man-worshipping girls.

There are other examples of the "good woman" in Hongkong films. May Kwan, as played by Anita Mui in Saviour of the Soul, 16 is a "city soldier" who fights with bomb-swords and leaps like Catwoman. Her bravery at work, however, does not transfer to her private life. Loved by her two best friends, she is too coy to express her feelings to the man she truly loves. Her timidness in romance also puts her perfectly and necessarily in the category of the pure-hearted virgin. She may be a fearless fighter, but she is still a woman; taking initiative in the love game is not too ladylike. A similar example is the moralistic mainland policewoman Shek Nam (played by Carol Cheng) in the Her Fatal Ways series. 17 Shek occupies a high position on the force but is totally naive about love and sex. When Shek Nam is helplessly attracted to a male counterpart on the Hongkong police force, she is frightfully disturbed by her own sexual awakening. Her new-found awareness presents a danger : will she still be as competent and tough if she succumbs to romance? Shek Nam denies her sexual role by acting like a man in order to secure her position in the male-dominated business of law enforcement. Loving a man would remind others of her true self : a woman, a subordinate.

When I learnt that the plot of The Heroic Trio ${ }^{18}$ concerned three Robin Hood-like women warriors fighting together against evil forces in a futuristic world, I had high hopes - maybe too high. I was hoping to see the return of the heroic women who first appeared in 1960s adventure films and achieved iconic status in King Hu's martial-arts classics during the 1970s. In Heroic Trio, Anita Mui is a superwoman whose hero identity is unknown even to her loving policeman husband. Like Superman, Anita swoops down from the sky at the moment of life and death to rescue the distressed and discipline the offenders. When she's not saving the world, she stays at home as a middle-class housewife instead of holding a day job at the office, like Clark Kent. As a wife, Mui's character is nurturing and loyal, always staying in the background.

Perhaps all these characters are a reflection of the situation and mentality of the new generation of women in Hongkong. They may have acquired the ability to be equal to their men, but prefer to hide their opinions and make their influence discreet or forget about their love life, if they want to hold on to their power. Unlike 
their counterparts in the West, most women in Hongkong choose not to openly challenge male authority. They know the price of such a transgression.

By far the most interesting female character in recent Chinese cinema, and one who has yet to appear in Hongkong cinema, is Qiu $\mathrm{Ju}$, the title character of mainland Chinese director Zhang Yimou's new film. ${ }^{19}$ Qiu Ju is a peasant woman who insists on seeking justice in the case of her husband's being kicked in the groin by the local village chief, which threatens the continuity of the family name. Although the reason for her tireless pursuit seems awfully regressive, her persistence in seeking fairness and dignity, which goes against almost everyone (including her husband), is utterly progressive. Qiu Ju is not well-educated, and does not fully understand contemporary legal concepts, however she has no need for physical power; she displays a moral strength that the omnipotent women warriors of Hongkong fantasies lack.

\section{Who Are the Men in Hongkong Cinema?}

\section{Michael Gilson}

A multitude of socio-cultural codes influence the way the principal audience for Hongkong movies (filmgoers of Chinese origin in the Crown Colony, throughout South-East Asia, and in the diaspora of Chinatowns in North America and elsewhere) perceives Hongkong movies : in other words, the reception of filmic texts by Chinese viewers is informed by their awareness of other texts that are part of the Chinese cultural tradition, a fact which could prove problematic for Western or other non-Chinese critics who approach Chinese cinema without some prior knowledge of specifically Chinese systems of meaning. 20

Hongkong society and culture have been somewhat more attuned, for obvious reasons, to outside ("Western") influences, than have the other Chinese regions (the mainland and Taiwan), and so the principal audience for Hongkong films carries as part of its cultural baggage a whole range of ideas that are "other" than those born of traditional Chinese ways of thinking. At the same time, those who create Hongkong films are influenced at once by traditional Chinese culture, including Chinese cinema, and by 
Western culture, including Hollywood movies. Representations of female and male personages in Hongkong cinema, and their perception by viewers, are thus created out of a complex network of influences. However, the "Western" component of these influences is filtered through a specifically Chinese paradigm. 21

\section{- aspirations to Femininity in the Traditional Chinese Construction of "Male"}

Before an examination of the portrayal of male and female characters in Hongkong films can proceed, some basic notion of the way traditional Chinese culture defines "male" needs to be elucidated. This has already been done in the context of Chinese film studies, in an analysis of the mainland Chinese film Red Sorghum by the American-based critic Wang Yuejin. Beginning with an explanation of the traditional Chinese metaphysical / philosophical concepts of yin and yang, whose corresponding attributes in nature are supposedly balanced (dark / cold / winter / night / female / down / stillness correspond to yin, and light / warm /summer / day / male / up / action to yang), Wang posits that they have in fact come to represent an unbalanced moral / ideological dichotomy, in that the prominence of yang prevails over the mostly absent yin, and hence male prevails over female; this is seen by Wang as being concordant with Confucian ethics, which refer to "the noble male and base female." These ideas in turn shaped the later Chinese feudalist patriarchy :

The hierarchical feudal order sought to structure itself around the figure of gender, with the ruler as the dominant male and the ruled as the submissive female.

The Buddhist and Daoist ways of looking at the world, Wang continues, exerted a further influence :

(...) the Chinese have long aspired to "internal stillness and passivity as a positive way to appropriate external reality. (...) As the aspired-to stillness and passivity have touches of femininity, femininity itself becomes a condition highly aspired to. 22

Wang goes on to propose that a "femininity complex" inhabits the collective Chinese unconscious. Chris Berry, in an article about the emergence of "macho" in mainland Chinese films, crystallizes Wang's ideas :

By the "femininity complex," Wang means that traditional Confucian-influenced discourses, whether philosophical or fictional, have long placed value on qualities held to be feminine. Obedience and passivity are preferred over independence and aggression, both perceived as masculine qualities. 23 
(I am reluctant to extend these ideas to the point of saying, as Wang does, that "femininity itself becomes a condition highly aspired to" : men's yearning for feminine qualities cannot translate into actual fact, because this would subvert male / female hierarchy in real life. The notion that male characters in various forms of Chinese fiction merely embody qualities seen as feminine, however, is central to the discussions that will come later in this article.)

For Wang and Berry, the echoes of this aspiration to feminine qualities 24 are seen in different Chinese cultural products ranging from traditional literature, to Chinese opera, and finally cinema. In classical Chinese fiction (works aimed at the literati of the upper classes), male protagonists are cast in the "gentleman scholar" mode : what we might term in the West as "feminine" qualities are valorized in men. The Chinese equivalent of the Western action hero only appears in the form of the outlaw bandits populating classic popular novels such as The Three Kingdoms and The Water Margin : these are rogues, not the cultivated scholars found in literature aimed at the upper classes. Less value is placed, then, on "masculine" values (again, "masculine" in the Western sense). It is interesting to note that the swordsman of popular martial-arts fiction - the most successful examples are those written by Kam Yung (Jin Yong) in the 1960s and which have clearly inspired recent Hongkong films like the Swordsman series - displays both "macho" and "feminine" values. Indeed, he is not only expected to possess fighting prowess, but also be well-versed in the refined, genteel arts of calligraphy and painting, like the gentleman scholar. It would seem, then, that as we move through history towards the emergence of the cinematic avatars of these male fictional characters, a certain balance of "feminine" and "masculine" qualities is present in the Chinese concept of "male."

Chinese opera is another important and influential cultural product that bears mention here : like literature, it also reflects culturally-constructed notions of gender. Even more interestingly, a certain "gender confusion" is part of the Chinese opera tradition. In Beijing opera, men regularly play women characters, and in the regional Shaoxing opera tradition, women play male characters. A number of Hongkong fantasy films contain echoes of this tradition, and I will touch upon this influence later.

The traditional cultural constructs that "tell Chinese men how to behave" have been eroded in modern Chinese communities, most especially the capitalist battleground of Hongkong, where the modern Chinese businessman must summon aggressiveness and 
competitiveness - Western symbols of masculinity. The gentleman scholar cannot survive in modern Hongkong. At the same time, in social situations and in marital and familial relationships, men are expected to be a see mun yan (siwen ren), or "genteel." Put simply, today's modern, successful Hongkong man is caught between his traditional Chinese past and his modern, Western present.

\section{- from Traditional Male Heroes to Gender Confusion in the Current Hongkong Cinema}

At present, the most popular hero figure in Hongkong cinema is the kung fu master Wong Fey-hong (Huang Feihong), who has so far appeared in three feature films directed by Tsui Hark, who is arguably the most influential Hongkong filmmaker of the past decade.25 The Wong Fey-hong character was previously the subject of nearly one hundred Hongkong films made mostly in the $1950 \mathrm{~s}$ and $60 \mathrm{~s}$, an icon of the Chinese martial arts movie, preBruce Lee. He is also a direct descendant of the martial-arts hero of popular literature, who displayed both fighting expertise as well as consummate skill in the other classical disciplines (Wong Feyhung is a doctor and founder of a martial arts school, a wise master who uses violence only when there is no alternative). The main difference between the new Wong Fey-hong and the old is his age : the Wong Fey-hong of the 1950 s and 60 s was most often played (on some eighty occasions, in fact) by Kwan Tak-hing, who was much older than the current incarnation, the mainland-born martial arts champion Jet $\mathrm{Li}$ (Li Lianjie). Li, simultaneously more virile and possessed of a cherubic innocence, turns Wong Feyhong into a romantic leading man. As such he is the perfect see mun yan hero for today's audience, with a certain "feminine" grace about him that complements the obvious "masculinity" that flows from his dazzling displays of kung fu.

In the so-called "hero films" of the late 1980 s, we see a grafting of archetypal martial-arts heroes onto a stylized, modern urban landscape, with fists, swords and other weaponry replaced by machine guns and other more technologically-derived instruments of violence. This is seen most memorably in the films of John Woo, of which The Killer 26 is one example. The star of most of these action films is Woo's favorite actor - indeed his on-screen alter ego - Chow Yun-fat. The modern-day descendant of the White Knight and the samurai, Chow can be a ruthless killer one moment and wax sentimental the next : he might be said to be very much in touch with his "feminine" side. The action hero in John Woo's universe, then, embodies feminine and masculine qualities, like the gentleman scholar, the swordsman, and Wong Fey-hong. 
Many critical discussions (both Western and Chinese) have taken the "buddy" characters in John Woo's films to yet another level, detecting a homoerotic subtext in them, most notably in The Killer. Could this be evidence of an effort on the part of the filmmaker to consciously subvert the rules of the action film genre by exploring an unconventional (in Hongkong at least) dimension of male relationships, something not seen in the more traditional martial-arts films like Once Upon a Time in China?

We shall see that manifestations of gender confusion, and by extension, a tentative exploration of homosexuality, appear in Hongkong's fantasy-adventure films, such as the Tsui Hark productions Peking Opera Blues 27 and Swordsman II. It is easy to see the echoes of the Chinese opera tradition in the former, since much of the action actually takes place in an opera house and one of the trio of female protagonists is an opera performer. In Swordsman II, the gender confusion of Chinese opera merges with the supernatural fantasy of $A$ Chinese Ghost Story. Beginning with her celebrated role as "Invincible Asia" in Swordsman II, the veteran female star Lin Ching-hsia has recently fashioned a second career of playing androgynous hero(in)es and villain(nesse)s, and almost every swordplay or costume film released since has featured one or more "gender-bender" characters. 28

You could see Invincible Asia's sexual mutation as the ultimate representation of the "aspiration to feminine qualities" discussed earlier. But Asia is the villain of Swordsman II; the (overwhelmingly young, male) audience is made to identify with Asia's opponent, Swordsman Ling, in the same way they respond to Wong Fey-hong (Ling is even played by the same actor, Jet Li). Ling is a playful, childish character who is not without touches of femininity. However, the filmmakers ultimately don't want to venture too far in their explorations : Swordsman Ling realizes during his final battle with Asia that $\mathrm{s} /$ he was once a man. He therefore cannot accept the fact that he had sex with her / him : this is too-great a threat to his maleness, to the source of his power, and this idea is transferred to the audience in no uncertain terms. Resolutely heterosexual, Ling can never reconcile his feelings and love Asia since s/he was once "male."

For a Western cinematic equivalent of this situation, compare the central character of Fergus in Neil Jordan's The Crying Game, who does come to love the transvestite Dil by the end of the film. This would seem to suggest that Hongkong cineastes (and their principal audience) are unprepared to tolerate the concept of love between two "males," and that Chinese society may not be prepared to accept the notion that one's "gender" is not strictly 
definable according to one's physiological characteristics, nor even definable as a socio-cultural construction of a heterosexual hegemony. 29 The current fascination with sexually ambiguous characters in Hongkong films, then, may be nothing more than a superficial one, attributable at once to the traditions and cultural influences which we have previously identified with respect to literature and opera and, in some measure, to the influence of current Western trends and fashions, and therefore does not necessarily reflect a conscious, profound subverting of the concepts of gender and identity. 30

Overt same-sex love and passion, whether gay or lesbian, are as yet not seen as anything more than a curiosity in Hongkong cinema. In the third and latest installment of the Swordsman series, The East Is Red, ${ }^{31}$ the filmmakers have Invincible Asia and her new (female) adversary, played by Joey Wong Tsu-hsien, play out a love scene that struck me as awkward. The scene (and similar ones in films such as $A$ Chinese Ghost Story $I I^{32}$ ) would seem to serve the sole purpose of titillating the heterosexual male viewer; at any rate, the affair between Invincible Asia and her lover / adversary is doomed, and so a true lesbian relationship is still taboo in the Hongkong cinema. Another example is the central lesbian character in the film Days of Being Dumb, ${ }^{33}$ who in the end must be "straightened out": she came to hate men in her youth, later found fulfillment in same-sex relationships, and finally enters into a "correct" hetero relationship.

Sex between male characters is completely absent in Hongkong cinema, and where gay male characters have shown up in Hongkong films, or where heterosexual characters allude in some way to homosexuality, they have tended to reflect negative stereotypes and usually serve to generate audience laughter. This negative view is often present in the sexploitation comedies of director Wong Jing and in those of mega-star Stephen Chiau Singchi, who (despite an undeniable gift for physical comedy and a commendable penchant for street-smart subversion of symbols of authority, displayed for example in Fight Back to School ${ }^{34}$ ) has basically built a career on locker-room humor of a type that is becoming increasingly "incorrect" to particular segments of Western society. Of course, Hollywood films and stars that depend on similar types of humor continue to make millions at the box office. Stephen Chiau's present popularity, and the reasons for it, are comparable to Eddie Murphy's in North America 7 or 8 years ago. In the West, mainstream films that try to reverse stereotypes and sexism are beginning to appear (Thelma \& Louise, for example), and there is a corresponding sensitization to 
negative stereotyping, at least on some levels. Is a similar shift happening in Hongkong? The early answer would have to be no : Chiau's mass acceptance among Chinese audiences leads me to think that, as in the West, the majority of the audience (which is in turn, mostly male) is not at all uncomfortable laughing along with an increasingly "politically incorrect" (for want of a better term) world view.

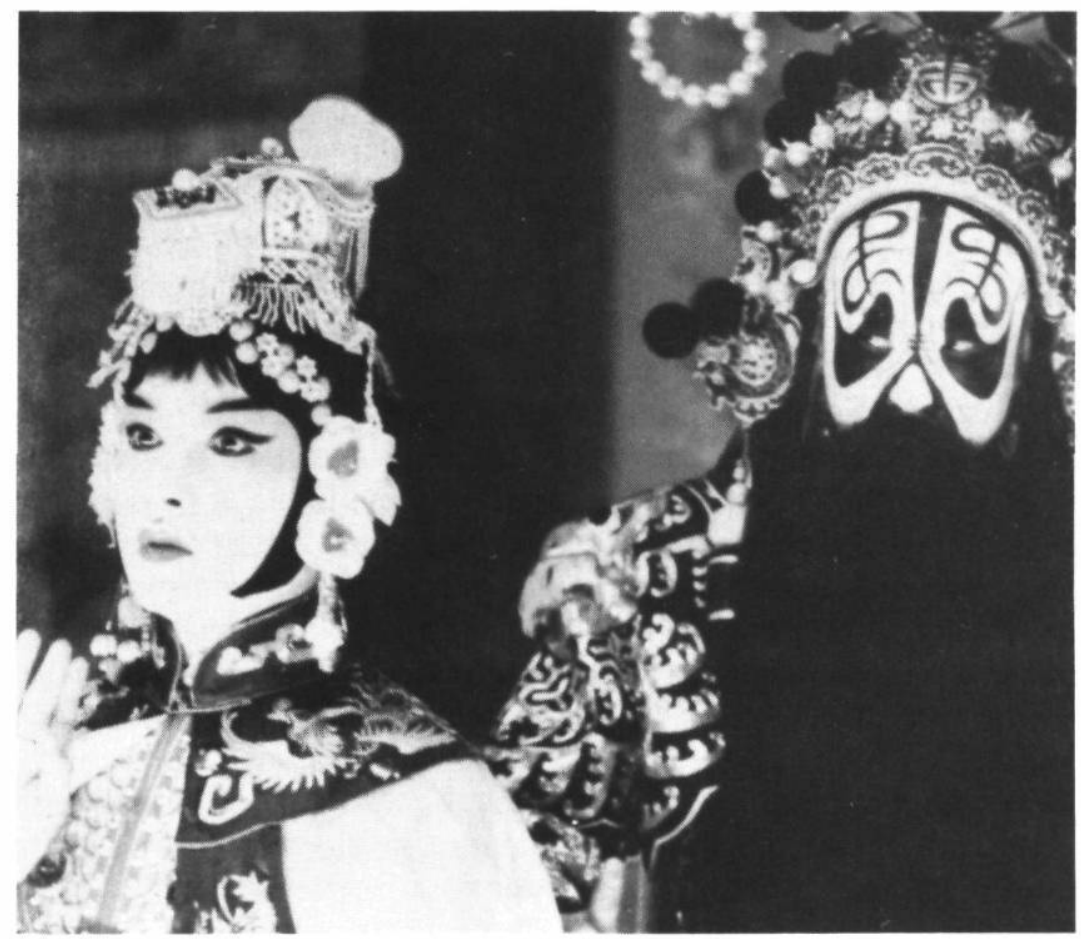

Adieu à ma concubine de Chen Kaige (1992)

One recent Chinese film which at first glance appears to be making serious attempts at addressing gay themes, doesn't seem, upon closer inspection, to be saying anything new or positive either. Mainland-born director Chen Kaige's newest work, Farewell To My Concubine, 35 is an epic account of the relationship between two male Beijing opera performers, from their days as young students in the years before the Communists' rise to power, through their persecution during the Cultural Revolution and eventual rehabilitation after the fall of the Gang of Four. Leslie Cheung, a major star of Hongkong cinema, plays Cheng Dieyi, who specializes in female opera roles, and Mainland 
Chinese actor Zhang Fengyi is his partner, Duan Xiaolou. After Concubine's release in Hongkong earlier this year, the handling of its gay content was the subject of critical debate which saw Chen Kaige accused of being homophobic. The evidence for this in the eyes of Chen's detractors is the portrayal of the young Beijing opera students' oppressive upbringing : the repeated scenes of the master disciplining them by caning their bare buttocks, and the young Dieyi's sexual abuse by a rich elderly patron, brought to mind the old — perhaps unprovable - argument that homosexuality is not innate but inculcated, and therefore can be "corrected". I tend to agree that such a mechanistic reduction of the explanation of gay identity to one single factor is highly problematic. It will be interesting to see the reaction in the Western critical arena once Concubine is released internationally : the stakes are high both in the West and in mainland China for this film, the first to deal overtly with gay themes.

The just-released Hongkong film Tom, Dick and Hairy 36 is a romantic comedy about three men who are roommates in a trendy district of Hongkong. The film manages to make a number of witty commentaries about relationships via an array of more-orless stock characters. Tom (Tony Leung Chiu-wai) plans to marry his long-time girfriend but falls for a (proverbially gold-hearted) dance-hall hostess named Cat. Dick (Tony Leung Kar-fei) is an incorrigible playboy working on a succession of nubile young conquests. Hairy, played by Lawrence Cheng, is a shy type who takes the video dating service route in his quest for the perfect match and, after a computer error, ends up meeting a gay man for lunch one day. The two hit it off. Initially, it seems Hairy accepts this affection because he needs it from someone, anyone. Their ensuing relationship stops short of the bedroom, but, significantly, the filmmakers are prepared to suggest that Hairy is ready to acknowledge his homosexuality. The gay friend, for his part, is presented as the weak, sensitive type, prone to crying jags. Hairy ends up resisting his sexual advances, and indeed is "rescued" from them by his roommates, Tom and Dick. This refutation is restated later, in the film's most unusual, and telling, scene : the three friends' anthropomorphized penises get up in the middle of the night and have a chat in the living room (they are played by the three lead actors, naked and with bald heads). Tom and Dick's dicks, proudly hetero, decide that Hairy's needs to be "straightened." The filmmakers play it safe as far as Hairy's homosexuality is concerned, but Tom and Dick's hetero lifestyles don't go unquestioned, either. In a cynical reversal of the dénouement one expects to see in this sort of comedy-romance, 
Tom marries Cat instead of his fiancée. The film flashes forward to reveal that Tom and Cat eventually settle into boring domesticity, they have a few kids, and Tom eventually has another mistress. Dick persists in his playboy ways until one day, the young girls no longer flock to dance with him at his favorite nightclub. In the end, writer-director Peter Chan is using a range of stereotyped characters to question all types of relationships, and there is a certain feminine side to all three male characters : they are all more sensitive than most men, more preoccupied with finding true love than "real men" are. In some ways, Tom, Dick and Hairy is more daring than what we are used to seeing in Western mainstream cinema, and may in time be seen as a transitional film for Hongkong cinema.

\section{Conclusion}

Time will no doubt tell whether Hongkong cineastes are going to push past the constraints on positive portrayals of women as well as gay and lesbian characters which we have seen operating in our discussion of recent Hongkong films. Chinese filmmakers and their audiences would do well to take a cue from the just-released film The Wedding Banquet, ${ }^{37}$ which looks to be a milestone work as far as honest and positive portrayals go. A co-production between Taiwan and the United States, The Wedding Banquet is about a young Chinese immigrant, Gao Wai-tung, living in New York City with his white lover, Simon. Wai-tung cannot come out to his Taiwanese parents, and so Simon proposes that he marry Wei-wei, a young artist from Mainland China : Wai-tung's parents will stop wondering about when their son is going to settle down, and Wei-wei will get her American citizenship. An elegant solution, it seems, until Mr. and Mrs. Gao decide to come to the United States for the wedding, setting off a chain of alternately farcical and dramatic episodes. Right from the film's opening scenes, director Ang Lee takes a bold stance in frankly and positively displaying Wai-tung and Simon's relationship, and never wavers from that stance. The Wedding Banquet's openness is certain to be praised by Western critics and international festival-goers; whether it will be accepted by Chinese audiences remains to be seen. 


\section{NOTES}

1 Press conference held at the Festival of Festivals, Toronto, September 14, 1992.

2 Sisters of the World Unite (Shasha Jiajia zhanqilai, Dir. Maisy Tsui, 1992) was written and produced by Sylvia Chang, and its crew was principally female. Sisters is a rare example of a Hongkong film that deals with women's stories.

3 The Taiwanese film That Day, at the Beach (Haitan de yitian, Dir. Edward Yang, 1983), produced by Sylvia Chang, and the Hongkong productions Passion (Zui ai, Dir. Sylvia Chang, 1986) and Mary From Beijing (Meng xing shifen, Dir. Sylvia Chang, 1992) are examples.

4 Prison on Fire II (Taofan, Dir. Ringo Lam, 1991) and Bullet in the Head (Diexue jietou, Dir. John Woo, 1991) are examples. By "all-male casts" I mean the principal characters; there are women in these films but their presence is almost incidental to the male-dominated action.

5 The best examples are Fight Back to School (Taoxue weilong, Dir. Gordon Chan, 1991), Once Upon a Time In China (Huang Feihong, Dir. Tsui Hark, 1991) and God of Gamblers III , Back to Shanghai (Shanghai tan dusheng, Dir. Wong Jing, 1991).

6 Actress (Ruan Lingyu, Dir. Stanley Kwan, 1991), Sisters of the World Unite, and The Twin Bracelets (Shuang zhuo, Dir. Huang Yu-shan) are examples.

7 This genre began with $A$ Better Tomorrow (Yingxiong bense, Dir. John Woo, 1986). It is also known as the "hero film."

8 To Be Number One (Bohao, Dir. Poon Man-kit, 1991), set in the 1960s, is a Hongkong equivalent of The Godfather. The two-part film Lee Rock (Lei Luo zhuan, Dir. Lawrence Ah Mon, 1991) also takes place in the 1960 s and is the fact-based story of a corrupt super-cop.

9 Magnificent Scoundrels (Qingsheng, Dir. Lee Lik-chi, 1991) is a slapstick tale of con artists. Armour of God II (Feiying jihua, Dir. Jackie Chan) is a globe-trotting fantasy about a Chinese James Bond. Once a Thief (Zongheng sihai, Dir. John Woo, 1991) is a caper comedy set on the French Riviera.

10 The Chinese term (nüqiangren) literally means "Lady Mogul."

11 Swordsman Hunt (Liuxing hudie jian, Dir. Michael Mak, 1993) is one of dozens of examples (of varying quality) of the current revival of wu xia pian, or swordplay films.

12 One of 1992's biggest box-office successes, Swordsman II (Dongfang bubai, Dir. Ching Siu-Tung, 1992) continues the adventures of Swordsman Ling, first chronicled in Swordsman (Xiao'ao jianghu, King Hu, Tsui Hark, Ching Siu-tung et al., 1990).

13 Justice, My Foot! (Shensiguan, Dir. To Kai-fung, 1992) was the highest-grossing film of the year in Hongkong.

14 Fong Sai-yuk (Fang Shiyu, Dir. Cory Yuen, 1993) is another film loosely based on a legendary kung fu hero in the tradition of Wong Fey-hong (see below). At the time of writing, the film was number one at the Hongkong box office.

15 Siu Fong-fong began her film career as a teenager in the mid-60s and dominated Hongkong screens for many years before going to the United States to study. She later moved into production, appearing in front of the cameras only sporadically. 
16 The critically-acclaimed Saviour of the Soul (91Shen diao xialü, Dir. Cory Yuen and David Lai, 1991) is a hybrid film, combining modern technology and a traditional martial-arts aesthetic, and set in a comic-book, futuristic netherworld.

17 Her Fatal Ways (Biaojie, ni hao!, Dir. Alfred Cheung, 1990) has already spawned two sequels; the strength of all three films is their humorous reflection on the relationship between mainland and Hongkong attitudes.

18 A critical and commercial failure, The Heroic Trio (Dongfang sanxia, Dir. To Kai-fung, 1993) stars Anita Mui, Maggie Cheung and Michelle Yeoh.

19 The Story of Qiu Ju (Qiuju da guansi, Dir. Zhang Yimou, 1992) is a co-production between China and Hongkong. Qiu Ju won the Golden Lion as best film, and its star Gong Li a Silver Bear as Best Actress, in the 1992 Venice Film Festival.

20 Cf. Jenny Kwok Wah Loh, "A Cultural Interpretation of the Popular Cinema of China and Hong Kong," in Chris Berry (ed.), Perspectives on Chinese Cinema (London : British Film Institute, 1991) 166-174.

21 I employ the term paradigm in its broad definition: "A paradigm - the model by which a culture constructs reality - moves into place as the effect of multitudinous forces: scientific, political, social, economic, and religious," in Betty Jean Craige, Reconnection : Dualism to Holism in Literary Study (Athens (Georgia) and London : The University of Georgia Press, 1988) 4.

22 Wang Yuejin, "Red Sorghum : Mixing Memory and Desire," in Chris Berry (ed.), Perspectives on Chinese Cinema (London : British Film Institute, 1991) 48-52.

23 Chris Berry, "China's Search for Real Men," in Festival international du cinéma chinois de Montréal, Catalogue to the 3rd edition (Montréal: InterCinéArt, 1990) 48-52.

24 I would qualify this concept by stressing that seeing shades of "femininity" in the Chinese construction of "male" relies on a Western perspective of gender definition in Chinese culture. What I might as a Westerner see as "feminine" qualities in Chinese men may not be so obviously perceived as such by a Chinese observer.

25 Once Upon a Time in China, Once Upon a Time in China II (Nan'er dang ziqiang, Dir. Tsui Hark, 1991) and Once Upon a Time in China III (Shiwang zheng ba, Dir. Tsui Hark, 1993) are the three films thus far released in the series. At the helm of the hugely successful Film Workshop production company, Tsui Hark and Ching Siu-tung have produced and/or directed the most popular films in the genre that blends traditional Chinese fantasy and martial arts genres with comedy, highly stylized cinematography, a frenetic editing style, and most importantly, special effects technology similar to that which rejuvenated the science-fiction film in Hollywood of the late 70s. Tsui Hark's Wong Fey-hong cycle and Ching Siu-tung's Chinese Ghost Story and Swordsman series have similarly revived the kung fu, swordplay and ghost genres in Hong Kong, using the fast pace of modern cinematic technique to bring them into the 1980 s and 1990 s.

26 The Killer (Diexue shuangxiong, Dir. John Woo, 1989), which enjoyed a measure of success internationally (so much so that an American remake is in the works), is about a retiring hit man (Chow Yun-fat) who agrees to take on one last job in order to pay for an operation that will restore the sight of an innocent bystander (Sally Yeh) blinded during one of his previous killings, and the cop (Danny Lee) who tracks him. 
27 Peking Opera Blues (Dao ma dan, Dir. Tsui Hark, 1986) is an adventure comedy about three women (Lin Ching-hsia, Sally Yeh, Cherie Chung) who become embroiled in the Republican Revolution of 1911.

28 Among the many examples are Tony Leung Kar-fei, who appears in Peking Opera drag and later reincarnates as a sexless Buddha, and crossdressing Carina Lau, both in Dong Cheng Xi Jiu (Dir. Jeff Lau, 1993) and Michael Hui in drag as the matriarch of the central family in All's Well, Ends Well, Too (Huatian xishi, Dir. Clifton Ko, 1993). The "gender-bending" craze can be traced to the androgynous "Tree Devil" in A Chinese Ghost Story (Qiannü youhun, Dir. Ching Siu-tung, 1987).

29 For an exhaustive discussion of these ideas, in a much wider context, see Judith Butler, Gender Trouble: Feminism and the Subversion of Identity (New York and London : Routledge, 1990).

30 I do not mean to imply that in the West, questioning of ingrained concepts of gender and identity is rampant in mainstream popular culture and movies, but it is increasingly seen in what is popularly known as the "fringe" or "avant-garde" territories of popular music, performance art and experimental film, among other disciplines; Hongkong culture is absorbing the aesthetics of these "marginal" areas to some extent.

31 Released earlier this year, The East Is Red (Fengyun zai qi, Dir. Ching Siu-tung, 1993) is the weakest entry in the Swordsman series, marred by an incomprehensible plot and formulaic repetition of elements from the previous films.

32 A Chinese Ghost Story III (Dao dao dao, Dir. Ching Siu-tung, 1991).

33 Days of Being Dumb (Afei yu Aji, Dir. Ko Shou-Liang, 1992)

34 The highest-grossing Hongkong film of 1991, Fight Back to School, stars Stephen Chiau as a narcotics officer who goes undercover, Kindergarten Cop-style, at an elite boys' school. Two sequels have already been released.

35 Farewell To My Concubine (Bawang bieji, Dir. Chen Kaige, 1992) is an example of the fairly recent phenomenon of prestige super-productions, often directed by mainland Chinese filmmakers, co-financed by Hong Kong, China and Taiwan, or combinations of the three regions.

36 Tom, Dick and Hairy (Fengchen sanxia, Dir. Peter Chan, 1993) was written and directed by a founding member of UFO, or United Filmmakers Organisation, a new alliance of young cineastes who are resisting the current mania for swordplay fantasies, producing interesting, "small" films and attempting, with some success, to circumvent the major studios' distribution monopoly.

37 The Wedding Banquet (Xiyan, Dir. Ang Lee (Li An), 1993) shared the Golden Bear for Best Film at the 1993 Berlin Film Festival.

\section{GLOSSAIRE DES PRINCIPAUX TERMES CHINOIS}

(par ordre alphabétique)

Afei yu Aji

Bawang bieji

Biaojie, ni hao

Bohao
阿飛與阿基

霸王別姬

表姐, 你好

跛豪 
Dao dao dao

Dao ma dan

Diexue jietou

Diexue shuangxiong

Dongcheng xi jiu

Dongfang bubai

Dongfang sanxia

Fang Shiyu

Feiying jihua

Fengchen sanxia

Fengyun zai qi

Haitan de yitian

Huatian xishi

Huang Feihong

Lei Luo zhuan

Liuxing hudie jian

Meng xing shifen

Nan'er dang ziqiang

neiren

nüqiangren

Qiannü youhun

Qingsheng

Qiuju da guansi

Ruan Lingyu

Shanghai tan dusheng

Shasha Jiajia zhanqilai

Shen diao xialü

Shensiguan

Shiwang zheng ba

Shuang zhuo

siwen ren

Taofan

Taoxue weilong
道道道

刀馬旦

㖼血街頭

㖼血隻雄

東成西就

東方不敗

東方三俠

方世玉

飛鷹計劃

風塵三俠

風雲再起

海灘的一天

花田喜事

黄飛鴻

雷洛傅

流星蝴蝶㓣

夢醒時分

男兒當自強 內人

女強人

倩女幽魂

情聖

秋称打官司

阮玲玉

上海灘賭聖

莎莎嘉嘉站起來

神鵰俠侣

審死官

獅王乎霸

隻鐲

斯文人

逃犯

逃學威龍 
wairen

wuxiapian

Xiyan

Xiao'ao jianghu

yang

yin

Yingxiong bense

Zongheng sihai

Zui ai
外人

武俠片

喜宴

笑傲江湖

陽

院

英雄本色

縱横四海

最爱 